\title{
ABUNDANCE AND DIVERSITY OF SEAGRASS AND MACROFAUNA IN THE INTERTIDAL AREAS WITH AND WITHOUT SEAWEED FARMING ACTIVITIES ON THE EAST COAST OF ZANZIBAR
}

\author{
Thomas J. Lyimo ${ }^{1}$, Esther F. Mvungi ${ }^{2}$, and Yunus D. Mgaya ${ }^{3}$ \\ ${ }^{1}$ Department of Molecular Biology and Biotechnology, University of Dar es Salaam P.O.Box \\ 35179 Dar es salaam. \\ E-mail:1yimo@amu.udsm.ac.tz \\ ${ }^{2}$ Department of Botany, University of Dar es Salaam P.O.Box 35060 Dar es Salaam. \\ ${ }^{3}$ Faculty of Aquatic Sciences and Technology, University of Dar es Salaam, P.O.Box35064 \\ Dar es Salaam
}

\begin{abstract}
The diversity and abundance of seagrass and associated macrofauna were studied in transects with and without seaweed farms at Chwaka Bay and Jambiani, in the East Coast of Zanzibar. Eight seagrass species, namely Cymodocea rotundata, Cymodocea serrulata, Thalassia hemprichii, Thalassodendron ciliatum, Syringodium isoetifolium, Halodule uninervis, Halophila ovalis and Enhalus acoroides were recorded in the transects. The mean total biomass of seagrass at Chwaka Bay ranged from $142.4 \pm 70.71$ to $1652 \pm 772.7 \mathrm{~g} \mathrm{dw} / \mathrm{m}^{2}$ and $212.9 \pm 146.2$ to $1829 \pm 1692 \mathrm{~g}$ $d w / m^{2}$ in station with and without seaweed farms, respectively. At Jambiani, the mean total biomass ranged from $880.4 \pm 336.8$ to $3467 \pm 549.9$ and $203.4 \pm 102.4$ to $3810 \pm 2770 \mathrm{~g} \mathrm{dw} / \mathrm{m}^{2}$ in station with and without seaweed farms, respectively. The overall total biomass of seagrass was significantly lower $(K W=108.7, p<0.0001)$ in station with seaweed farms than in stations without seaweed farms. A total of 93 macrofauna species representing 60 families were encountered and the mean density ranged from 910 to 6990 individuals $/ \mathrm{m}^{2}$ at Chwaka Bay and Jambiani in stations with and without seaweed farms respectively. The most common macrofauna species were Codakia punctata, Meropesta nicobarica, Echinometra mathaei, Pinna muricata and Clibanarius emystemus. It was shown that the macrofauna abundance and diversity was higher in stations without seaweed farms than in the stations with seaweed farms, which could be due to activities associated with seaweed farming which contributed to the loss of diversity and biomass of flora and macrofauna of the seagrass meadows.
\end{abstract}

\section{INTRODUCTION}

Seagrasses are marine angiosperms with a worldwide distribution. Taxonomically it is quite a small group with only a total of around 60 species (den Hartog 1984). However, their ecological importance is undisputed. Seagrass ecosystems are one of the main components within the tropical seascape (Moberg and Rönnbäck 2003) and their presence causes a dramatic increase in biodiversity of both plants and animals as they act both as shelter for juvenile animals and as a foraging and nursery area for many animal species (Larkum et al. 1989, Duarte 2002). Furthermore, they have a main function as stabilizers of tropical coastal habitats as they trap nutrients and sediments carried from terrestrial effluents, protecting coral reefs from turbid waters and beaches from wave erosion.

Temporal variability in seagrass area has been found to occur in response to either anthropogenic or natural disturbances (Wakibia 1995, Short and Wyllie-Echeverria 1996; Creed and Amado Filho 1999, Duarte 2002, Green and Short 2003). Reduction or absence of seagrass habitats is quite often associated with reduction of valuable resources, e.g. fish. Seagrasses in shallow bays are damaged by vessel anchors and chain sweeps, by vessel hulls and by disturbing and eroding sediments from vessel propulsion. Discharges from 
agriculture runoff, industrial runoff and domestic sewage may contain a lot of organic and inorganic nutrients, chlorines and some heavy metals which may damage seagrass ecosystems (Lobban and Harrison 1994, Lugendo et al. 1999). In the Western Indian Ocean (WIO) region, the documented disturbances to seagrass habitats include manual removal of seagrasses for hotel development in Mauritius (Daby et al. 2003), beach cleaning activities (Ochieng and Erftemeijer 2003) and the uprooting of seagrasses for invertebrate collection (Bandeira and Gell 2003) or seaweed farming (de la Torre Castro and Rönnbäck 2004, Lyimo et al. 2006).

Impact from vessels and effluent can result in sub-lethal effects such as increased epiphyte load, decreased productivity, loss of associated fauna, or lead to broad scale reduction in seagrass cover. Wherever the levels of disturbances are less, recovery might occur but if the impact is beyond threshold, the meadow will not survive such chronic situation and it will continue to deteriorate.

Seaweed farming is often considered a suitable form of aquaculture, and has significantly contributed to poverty reduction and financial revenues to producers like Zanzibar (Tanzania) in the Western Indian Ocean (Msuya 1993, PettersonLofquest 1995, Ronnback et al. 2002, Shechambo et al. 1996, Msuya 2006). However, there is growing data suggesting that seaweed farming has an effect on the seagrass biomass and associated fauna (Msuya et al. 1996, Semesi 2002, de la Torre-Castro and Ronnback 2004, Eklof et al. 2005). The effects also seems to be transferred to higher trophic levels e.g. macroscopic infauna (Eklof et al. 2005) large invertebrate epifauna and fish community (Bergman et al. 2001, Eklof et al. 2006). Current existing studies on the effect of seaweed farming on seagrass ecosystem were based on the data collected in one season (Semesi 2002, Lyimo et al.
2006) and in one location e.g. Chwaka Bay (Eklof et al. 2005). None of these researches took into consideration the temporal and spatial variation. In the present study we present data collected at Chwaka Bay and Jambiani in dry and wet seasons. The differences between stations with and without seaweed farms are discussed in terms of seagrass and macrofauna diversity and abundance.

\section{MATERIALS AND METHODS \\ Study sites}

The study was conducted at two sites, Chwaka Bay and Jambiani on the East Coast of Zanzibar (Fig. 1). Chwaka Bay is an intertidal lagoon situated at latitude $6^{\circ} 10^{\prime} \mathrm{S}$ and longitude $39^{\circ} 26^{\prime} \mathrm{E}$. Its mean water depth is $3.2 \mathrm{~m}$ and the centre part of the Bay is dominated by tidal flats and channels, covered with mixed and monotypic stands of seagrasses. The dominant seagrass species are Thalassia hemprichii, Cymodocea serrulata, Cymodocea rotundata, Enhalus acoroides and Thalassodendron ciliatum (Eklof et al. 2005). Seaweed farming activities take place on some of the intertidal flats between channels close to the main village (Chwaka) around the Bay.

Jambiani is located at $6^{\circ} 6^{\prime} \mathrm{S}, 39^{\circ} 32$, E. The reef of Jambiani is far from the beach and the intertidal lagoon is wide. The dominant seagrass species at this site was $T$. hemprichii.

\section{Sampling design and laboratory analysis} In each site, two transects running perpendicular to the shoreline were set, one passing through seaweed farms and the other in an area without seaweed farms. At each of these transects, two sub-transects parallel to the shoreline at middle tide zone (100-150 $\mathrm{m}$ from shoreline) and low tide zone (only exposed during spring tides) was established. Thus, a total of 8 sub-transectsabbreviated CAM, CAL, CBM, CBL, $\mathrm{JAM}, \mathrm{JAL}, \mathrm{JBM}$ and JBL, referred to as sampling stations, were established. Systematic labeling was carried out as 
follows: Chwaka Bay (C); Jambiani (J); non-seaweed farms (A); crossing seaweed farms (B); middle tide zone (M) and low tide zone (L). In each station, 6 quadrats $(0.5 \mathrm{~m} \mathrm{x} 0.5 \mathrm{~m})$ were laid at intervals of 10 $\mathrm{m}$ apart and samplings were done to cover rain (March 2003, May 2003 and May 2004) and dry (August 2003, November 2003 and March 2004) seasons.

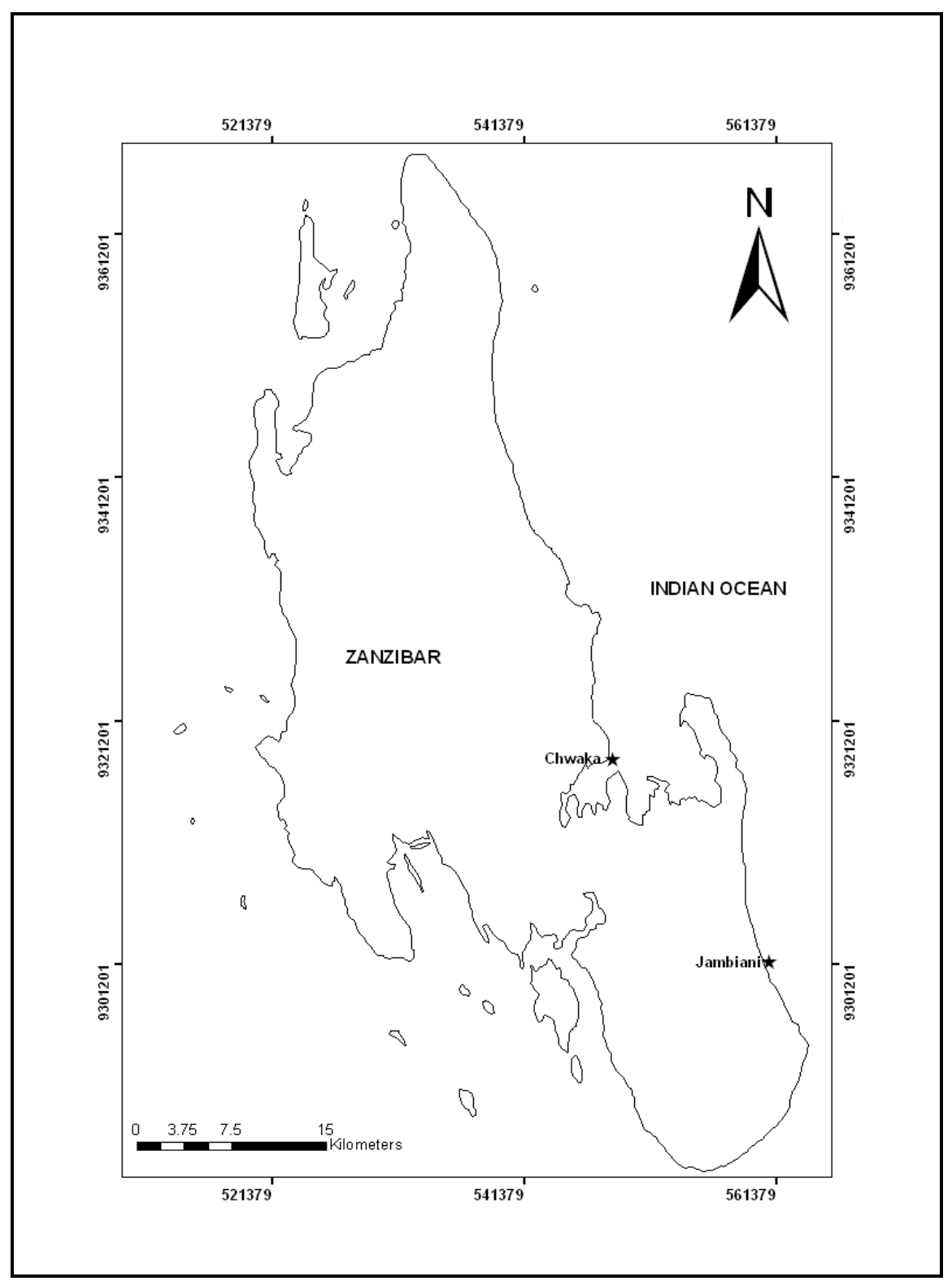

Figure 1: $\quad$ Map of Zanzibar showing the study sites $(\star)$ 
Identification of seagrass species found in and outside the quadrats was done in situ based on various field guide manuals (e.g. Richmond 2002, Oliveira et al. 2005). The epifauna determination was done by counting and collecting some specimens (for identification) falling in a quadrat. Samples for seagrass biomass and infauna were collected by a corer (inside diameter: 6.7 $\mathrm{cm}$; depth: $\sim 10 \mathrm{~cm}$ ). In the laboratory, all collected seagrass shoots were cleaned in fresh water and the above and below ground (rhizome) biomass was determined after drying in an oven at $60^{\circ} \mathrm{C}$ until constant weight was attained (Short and Coles 2001). The samples for infauna species were cleaned by rinsed through a $0.5 \mathrm{~mm}$ sieve and fixed in $10 \%$ borax buffered formalin. All macrofauna were sorted using stereo microscope (10 $\mathrm{x}$ magnification) and identified to at least genus level according to Richmond 2002 and Holdich and Jones 1983).

\section{Statistical analysis}

To analyse the differences between stations and between sites, the data were subjected to normality and homogeneity of variance tests. Where assumption for parametric test was met, one way analysis of variance (ANOVA) with its post hoc Tukey-Kramer's multiple comparisons was used. Where assumptions for parametric test were not met, data were transformed $\left(\log _{10}\right)$ or performed the non-parametric Mann Whitiney U test or Kruskal-Wallis Median test followed by Dunn's multiple comparisons test. The significance level was set at $\alpha=0.05$. Species diversity index was calculated from the Shannon-Wiener Index using the formula $H^{\prime}=-\sum p i \ln p i$ as described in Zar (1996).

\section{RESULTS \\ Seagrass species diversity and biomass}

Eight seagrass species namely Cymodocea rotundata Ehrenberg et Hemprich ex Ascherson, Cymodocea serrulata (Brown) Ascherson et Magnus, Thalassia hemprichii (Ehrenberg) Archerson, Thalassodendron ciliatum (Forsskal) den Hartog, Syringodium isoetifolium (Ascherson) Dandy, Halodule uninervis (Forsskal) Ascherson, Halophila ovalis (Brown) Hooker f., and Enhalus acoroides (Linnaeus f.) Royle, were encountered during this study in both sites, Chwaka Bay and Jambiani (Table 1). The most common species in all stations was $T$. hemprichii followed by $C$. rotundata and $H$. uninervis while $S$. isoetifolium and $T$. ciliatum were rare and most of them were seen in the lower tide zone or occurred in the sub-tidal areas. Out of eight seagrass species encountered, $C$. serrulata did not occur in transects sampled at Chwaka Bay. In Jambiani only four species namely $T$. hemprichii, $C$. rotundata, $C$. serrulata and $H$. univervis were found in the sampled transect. E. acoroides which is common in Chwaka Bay was absent at Jambiani. Moreover, the diversity of seagrass species was found to be slightly higher at Chwaka Bay $\left(H^{\prime}=1.29\right)$ than at Jambiani $\left(H^{\prime}=0.39\right)$.

The seagrass biomass (above and below ground) at different stations and seasons are shown in Fig. 2 a - d. The mean total biomass of seagrass at Chwaka Bay ranged from $212.9 \pm 146.22$ to $1828.8 \pm 1692.1$ and $142.37 \pm 70.71$ to $1652.2 \pm 772.67 \mathrm{~g}$ dry wt $\mathrm{m}^{-2}$ in non-seaweed and seaweed farm transects, respectively. There was a significant difference in total biomass among stations $(\mathrm{F}=9.82, \mathrm{p}<0.0001)$ with higher total biomass recorded in the low tide stations than the middle tide stations at both seaweed $(\mathrm{p}<0.001)$ and non-seaweed $(\mathrm{p}<$ $0.05)$ stations. There was a significantly higher seagrass biomass in the non-seaweed than in the seaweed farmed stations ( $\mathrm{U}^{\prime}=$ 6065.0, $\mathrm{p}<0.0001)$. 
Table 1: Frequency of occurrence of seagrass species in the sampling stations: 0 - 6 represent number of quadrats where the species was recorded; $0=$ species was not found in any quadrats, $6=$ species was found in all quadrats.

\begin{tabular}{lccccccccc}
\hline \multirow{2}{*}{ Species } & \multicolumn{1}{c}{ Frequency of occurrence in various sub transects } \\
\cline { 2 - 9 } & CAM & CAL & CBM & CBL & JAM & JAL & JBM & JBL \\
\hline Enhalus acoroides & 0 & 6 & 0 & 6 & 0 & 0 & 0 & 0 \\
Thalassia hemprichii & 6 & 4 & 3 & 5 & 6 & 6 & 6 & 5 \\
Thalassodendron ciliatum & 0 & 0 & 0 & 0 & 0 & 0 & 0 & 0 \\
Cymodocea rotundata & 6 & 1 & 6 & 0 & 3 & 0 & 5 & 2 \\
Cymodocea serrulata & 0 & 0 & 0 & 0 & 0 & 0 & 0 & 0 \\
Syringodium isoetifolium & 0 & 0 & 0 & 0 & 0 & 0 & 0 & 0 \\
Halophila ovalis & 2 & 0 & 1 & 0 & 0 & 0 & 0 & 0 \\
Halodule uninervis & 6 & 0 & 3 & 0 & 0 & 0 & 6 & 2 \\
\hline
\end{tabular}

Number of species

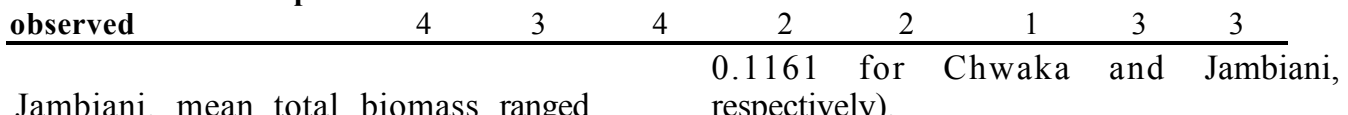

At Jambiani, mean total biomass ranged from $305.6 \pm 280.7$ to $3466 \pm 549.9 \mathrm{~g}$ dry wt $\mathrm{m}^{-2}$ in station with seaweed farms (JBM) and without seaweed farms (JAL), respectively. Unlike Chwaka Bay, there were no significant differences in seagrass biomass between the middle tide zone and low tide zone. However, there were significantly higher $\left(\mathrm{U}^{\prime}=2610, \mathrm{p}<0.0001\right)$ seagrass biomass in the non-seaweed areas as compared to the seaweed farmed areas. When comparing the two sites, the total biomass of seagrasses at Jambiani was significantly higher than at Chwaka Bay $\left(\mathrm{U}^{\prime}=8606, \mathrm{p}<\right.$ $0.0001)$. The overall total biomass of seagrass in stations without seaweed farms for both Chwaka and Jambiani sites was significantly higher than in the stations with seaweed farms $(\mathrm{KW}=108.7, \mathrm{P}<0.0001)$. The below ground biomass was in all sites were generally higher than the above ground biomass but the significance different was found at Jambiani $\left(\mathrm{U}^{\prime}=1001, \mathrm{p}=0.0001\right)$ only. When data collected during rain and dry season were compared, there were no significant differences in seagrass biomass between the two seasons at both sites $\left(\mathrm{U}^{\prime}=\right.$ 5664, $\mathrm{p}=0.1694$ and $\mathrm{U}^{\prime}=1977, \mathrm{p}=$ respectively).

\section{Macrofauna diversity and abundance}

A total of 93 species of macrofauna representing 60 families were recorded both sites (Table 2). The most frequently observed macrofauna species were Codakia punctata, Eurythroe complanata, Tectus mauritianus, Xestospongia exigua, Pinna muricata, Ophiocoma scolopendrina, Baseodiscus delineatus, Cleosiphon aspergillus, Cyprea annulus and Gafrarium pectinatum. There were higher diversity of macrofauna in transects without seaweed farms than in transects with seaweed farms. The Shannon-Weaver diversity index $\left(\mathrm{H}^{\prime}\right)$ of epifauna was 2.0 and 3.1 in areas with and without seaweed farms respectively, while the infauna diversity index was 2.4 and 2.7 in area with and without seaweed farms, respectively. When the two stations were compared, the average diversity of macrofauna species at Jambiani $\left(\mathrm{H}^{\prime}=2.6\right)$ was slightly higher than at Chwaka Bay $\left(\mathrm{H}^{\prime}\right.$ $=2.4$ ). The most abundant species recorded at Chwaka Bay and Jambiani were $C$. punctata and E. mathaei, respectively. 

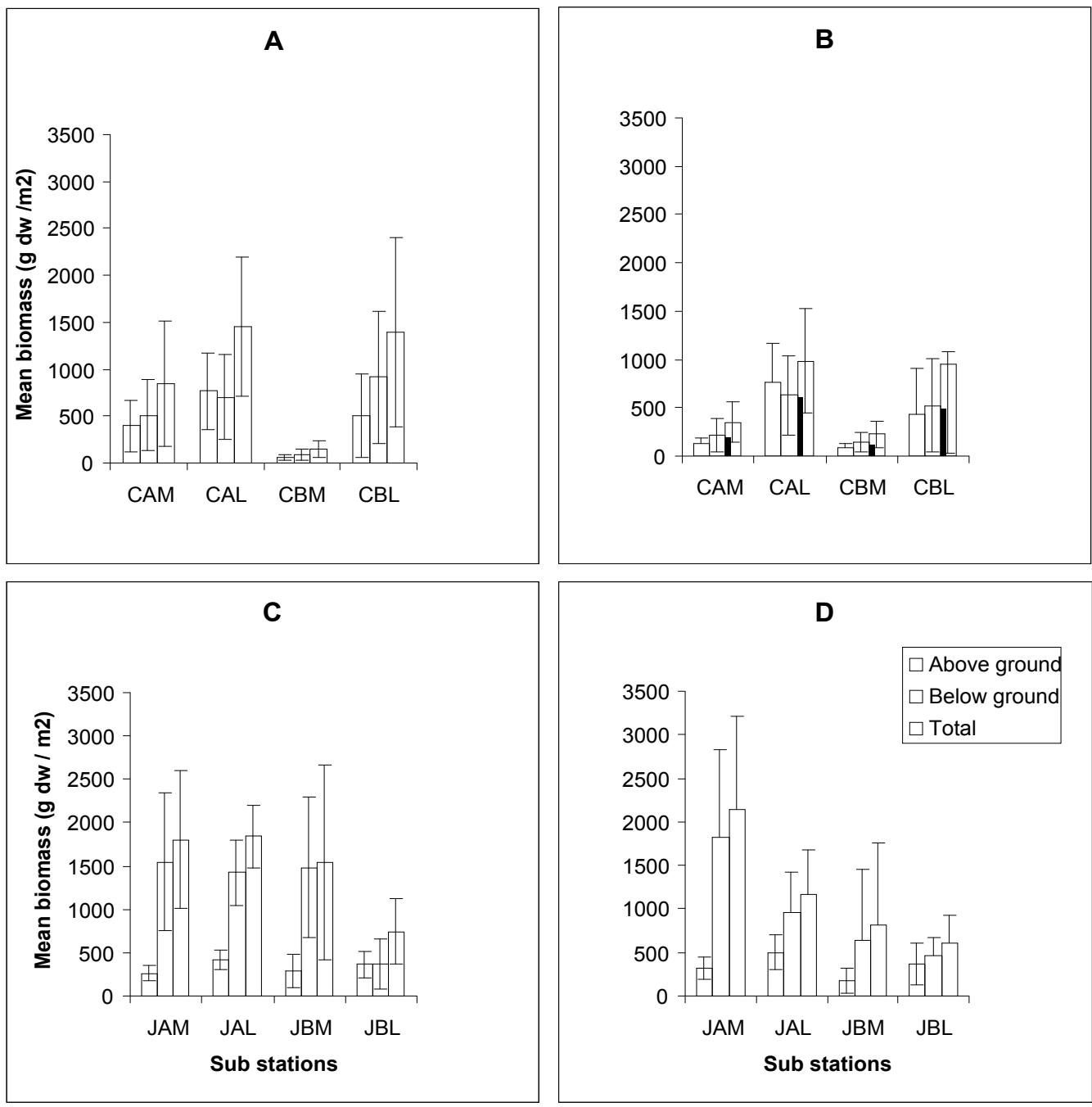

Figure 2: Seagrass biomass in various sampling stations during rainy and dry seasons; $\mathrm{A}=$ Chwaka Bay dry season, $\mathrm{B}=$ Chwaka Bay rainy season, $\mathrm{C}=$ Jambiani dry season and $\mathrm{D}=$ Jambiani rainy seasons. Vertical bars represent $\pm \mathrm{SD}$. 
The average total density of macrofauna ranged from 910 to 6990 individuals $/ \mathrm{m}^{2}$ recorded at Chwaka Bay and Jambiani in stations with and without seaweed farms respectively (Table 2). The mean total macrofauna density at Chwaka Bay ranged from 910 to 5811 individuals $/ \mathrm{m}^{2}$ in stations with seaweed farms (CBM) and without seaweed farms (CAL), respectively. Generally, there were significant differences in density of epifauna $(\mathrm{KW}=20.1, \mathrm{p}<$ $0.0002)$ and infauna $(\mathrm{KW}=19.32, \mathrm{p}=$
0.0002) at different stations. However, significantly high density of epifauna was found at CAM compared to other stations. When comparing seaweed and non-seaweed farming stations, the density of epifauna was significantly higher in the station without seaweed farms than the area with seaweed farms $\left(U^{\prime}=1744, p=0.0006\right)$. On the other hand infauna density was significantly higher at $\mathrm{CBL}(\mathrm{F}=6.9, \mathrm{p}<0.001)$ than in other stations.

Table 2: $\quad$ Macrofauna abundance $\left(\mathrm{N} / \mathrm{m}^{2}\right)$ in the sampling stations at Chwaka Bay and Jambiani

\begin{tabular}{|c|c|c|c|c|c|c|c|c|c|}
\hline \multirow{2}{*}{\multicolumn{2}{|c|}{ Taxon }} & \multicolumn{8}{|c|}{ Stations } \\
\hline & & CAM & CAL & CBM & CBL & JAM & JAL & JBM & JBL \\
\hline 1 & Amphinomidae & 107 & 113 & 0 & 70 & 3 & 1255 & 328 & 0 \\
\hline 2 & Amphiuridae & 0 & 5 & 8 & 0 & 12 & 0 & 56 & 0 \\
\hline 3 & Anopla (class) & 1290 & 54 & 66 & 169 & 800 & 675 & 167 & 0 \\
\hline 4 & Aplysinellidae & 0 & 0 & 62 & 0 & 5 & 0 & 0 & 0 \\
\hline 5 & Arcidae & 0 & 0 & 0 & 0 & 691 & 0 & 105 & 0 \\
\hline 6 & Aspidosiphonidae & 414 & 49 & 0 & 71 & 91 & 0 & 79 & 0 \\
\hline 7 & Capitellidae & 0 & 210 & 0 & 0 & 59 & 0 & 0 & 0 \\
\hline 8 & Cephalaspidea (order) & 0 & 49 & 0 & 0 & 0 & 591 & 0 & 0 \\
\hline 9 & Chalinidae & 5 & 0 & 0 & 0 & 0 & 39 & 0 & 5 \\
\hline 10 & Conidae & 0 & 0 & 0 & 0 & 473 & 0 & 0 & 0 \\
\hline 11 & Coralliophilidae & 0 & 0 & 0 & 0 & 405 & 0 & 0 & 443 \\
\hline 12 & Costellariidae & 0 & 0 & 0 & 0 & 24 & 0 & 79 & 0 \\
\hline 13 & Cypraeidae & 56 & 3 & 0 & 78 & 16 & 709 & 5 & 0 \\
\hline 14 & Desmacellidae & 0 & 0 & 0 & 11 & 0 & 0 & 0 & 0 \\
\hline 15 & Dialidae & 0 & 0 & 0 & 0 & 0 & 0 & 0 & 66 \\
\hline 16 & Diogenidae & 27 & 0 & 0 & 5 & 217 & 3 & 0 & 16 \\
\hline 17 & Donacidae & 1236 & 0 & 0 & 0 & 0 & 0 & 0 & 0 \\
\hline 18 & Echinometridae & 0 & 0 & 0 & 0 & 11 & 7 & 82 & 41 \\
\hline 19 & Epitoniidae & 0 & 0 & 0 & 0 & 0 & 148 & 0 & 273 \\
\hline 20 & Eunicidae & 107 & 0 & 0 & 74 & 0 & 0 & 328 & 0 \\
\hline 21 & Fasciolaridae & 0 & 0 & 0 & 11 & 0 & 0 & 0 & 0 \\
\hline 22 & Golfingiidae & 0 & 0 & 0 & 0 & 0 & 79 & 0 & 0 \\
\hline 23 & Grapsidae & 0 & 0 & 0 & 0 & 0 & 177 & 0 & 0 \\
\hline 24 & Holothuriidae & 0 & 3 & 0 & 3 & 0 & 0 & 0 & 0 \\
\hline 25 & Hymenosomatidae & 0 & 62 & 84 & 0 & 0 & 0 & 0 & 0 \\
\hline 26 & Lucinidae & 99 & 3123 & 0 & 1756 & 85 & 5 & 1013 & 11 \\
\hline 27 & Lysiosquillidae & 0 & 0 & 66 & 0 & 0 & 0 & 0 & 0 \\
\hline 28 & Macrophthalminae & 8 & 0 & 0 & 0 & 0 & 0 & 0 & 0 \\
\hline 29 & Mactridae & 0 & 1511 & 66 & 696 & 5 & 0 & 0 & 0 \\
\hline 30 & Mitridae & 45 & 0 & 0 & 8 & 0 & 0 & 0 & 0 \\
\hline 31 & Muranidae & 0 & 0 & 0 & 0 & 3 & 0 & 0 & 0 \\
\hline 32 & Muricidae & 0 & 0 & 0 & 0 & 0 & 5 & 0 & 0 \\
\hline
\end{tabular}




\begin{tabular}{|c|c|c|c|c|c|c|c|c|c|}
\hline 33 & Nassaridae & 45 & 0 & 13 & 11 & 3 & 3 & 0 & 0 \\
\hline 34 & Naticidae & 8 & 0 & 0 & 0 & 0 & 0 & 0 & 0 \\
\hline 35 & Nereididae & 131 & 79 & 47 & 0 & 0 & 0 & 0 & 0 \\
\hline 36 & Ocypodidae & 3 & 0 & 0 & 0 & 0 & 1637 & 0 & 0 \\
\hline 37 & Olividae & 0 & 54 & 0 & 0 & 0 & 0 & 0 & 0 \\
\hline 38 & Onchidiidae & 0 & 0 & 0 & 6 & 0 & 0 & 0 & 0 \\
\hline 39 & Ophiocomidae & 18 & 0 & 28 & 0 & 149 & 5 & 211 & 0 \\
\hline 40 & Ophionereidae & 0 & 0 & 0 & 0 & 0 & 5 & 3 & 0 \\
\hline 41 & Orbiniidae & 0 & 0 & 0 & 0 & 0 & 0 & 66 & 0 \\
\hline 42 & Ovulidae & 0 & 0 & 3 & 0 & 0 & 0 & 0 & 0 \\
\hline 43 & Paguridae & 5 & 0 & 0 & 0 & 0 & 0 & 0 & 0 \\
\hline 44 & Petrosiidae & 11 & 7 & 0 & 107 & 18 & 20 & 0 & 8 \\
\hline 45 & Phascolosomatidae & 132 & 49 & 79 & 0 & 131 & 675 & 0 & 0 \\
\hline 46 & Phyllodocidae & 0 & 0 & 0 & 0 & 0 & 0 & 0 & 79 \\
\hline 47 & Pilimnidae & 3 & 0 & 0 & 0 & 0 & 0 & 0 & 0 \\
\hline 48 & Pinnidae & 0 & 5 & 8 & 0 & 142 & 36 & 0 & 164 \\
\hline 49 & Portunidae & 16 & 0 & 0 & 196 & 71 & 0 & 0 & 443 \\
\hline 50 & Sipunculidae & 709 & 0 & 79 & 84 & 0 & 546 & 473 & 591 \\
\hline 51 & Strombidae & 0 & 0 & 0 & 0 & 3 & 0 & 0 & 0 \\
\hline 52 & Suberitidae & 3 & 0 & 0 & 84 & 0 & 0 & 0 & 0 \\
\hline 53 & Tellinidae & 330 & 0 & 162 & 0 & 394 & 0 & 417 & 0 \\
\hline 54 & Temnopleuridae & 0 & 0 & 3 & 0 & 0 & 5 & 0 & 0 \\
\hline 55 & Terebridae & 0 & 190 & 0 & 0 & 0 & 0 & 0 & 0 \\
\hline 56 & Tomopteridae & 0 & 54 & 0 & 0 & 0 & 0 & 0 & 0 \\
\hline 57 & Toxopneustidae & 0 & 0 & 0 & 0 & 4 & 11 & 11 & 3 \\
\hline 58 & Trochidae & 21 & 5 & 0 & 5 & 5 & 70 & 236 & 79 \\
\hline 59 & Veneridae & 333 & 120 & 70 & 28 & 317 & 124 & 134 & 0 \\
\hline \multirow[t]{2}{*}{60} & Xanthidae & 0 & 66 & 66 & 0 & 62 & 158 & 0 & 170 \\
\hline & Total mean abundance & 5162 & 5811 & 910 & 3473 & 4198 & 6989 & 3794 & 2391 \\
\hline
\end{tabular}

At Jambiani, the average total density ranged from 2391 to 6990 individuals $/ \mathrm{m}^{2}$. The minimum value was recorded in a station with seaweed farms (JBL) while the maximum value was recorded in a station without seaweed farms (JAL). There was no significant difference in epifauna density among stations, however infauna density varied significantly among stations $(\mathrm{p}<$ $0.0001 ; \mathrm{KW}=21.65)$, being significantly higher at JAM than other stations (JBM, P $<0.01$; JBL, $\mathrm{p}<0.001)$. A comparison of areas with and without seaweed farming revealed no significant differences in epifauna density; however, infauna density was significantly higher in area without seaweed farms than seaweed farmed areas ( $p$ $<0.0001$; U' $=3581$ ). The total macrofauna (infauna + epifauna) abundance was significantly higher in stations without seaweed farms $\left(p=0.03 ; U^{\prime}=3126\right)$.

Generally, macrofauna abundance was significantly higher $\left(\mathrm{U}^{\prime}=11765, \mathrm{p}=\right.$ 0.0473 ) in areas without seaweed farms than in areas with seaweed farms, indicating that seaweed farming activities have negative effects on the macrofauna species found in the seagrass beds.

\section{DISCUSSION}

The eight seagrass species encountered during this study were similar to those reported by Den Hartog (1984) who described 10 seagrass species for Unguja Island, Zanzibar. The only species that did not occur in the studied stations were Halophila stipulacea (Forsskal) Ascherson and Halodule wrightii Ascherson. The two species occur in small quantities in the 
intertidal areas of Unguja and therefore it is likely to be missed in a particular sampling station.

The seagrass biomass values were within a range of other reports in the region (e.g. Martin and Bandeira 2001, Eklof et al. 2005, Lyimo et al. 2006). Generally, the above-ground biomass was lower than below-ground biomass (Fig. 2), which might indicate the survival strategies of seagrasses to minimize anthropogenic pressure, exposure to desiccation at low tide and to increase stability when exposed to high tides. It was clearly shown that the total biomass of seagrasses was significantly higher in the station without seaweed farming activities as compared to the farmed stations. Similarly, macrofauna diversity and abundance, were significantly lower in seaweed farming station than unfarmed stations, suggesting that the seaweed farming activities have negative effects on the seagrass meadows and other organisms therein. Low abundance of macrofauna species in farmed areas could also be associated with physical removal, as some of these are used for food particularly shellfish, and may be collected when visiting seaweed farms (pers. observation). The meadows formed by seagrasses have characteristics that make them a suitable habitat for many animals, such as fishes and crustaceans (e.g. Coen and Heck 1991). The high primary production of the seagrass ecosystems ensures an abundant supply of energy, and the three-dimensional structure of the vegetation offers hiding places that protect against predation. Another factor that makes seagrasses important in coastal ecosystems is the fact that they provide an extensive area for epiphytes to utilize as a living space (Hamisi et al. 2004). The effect of this is an ecosystem with high diversity and a larger number of individuals within the community, compared to ecosystems without seagrasses (Fortes 1988, Coles et al. 1985).
The reason for low seagrass biomass in Chwaka Bay as compared to Jambiani may be site specific. At Chwaka Bay, seaweed farms are established in areas with seagrasses while the preferred substrate at Jambiani is sandy. As a consequence farmers at Jambiani leave patches of seagrass meadows less disturbed. However, some farmers uproot seagrasses manually to open up areas for seaweed farms (Lyimo et al. 2006). Shading and competition for nutrients in the water has been suggested to be among the factors that might result into reduction of primary productivity and growth rates and hence biomass of seagrass (Eklöf et al. 2005). However, Lyimo et al. (2006) showed that there was no significant difference in primary productivity and growth rates between seagrass meadows at Chwaka Bay and Jambiani. The possible reasons remain mechanical abrasion by the algal fronds, trampling and deliberate removal of seagrasses by farmers (de la Torre Castro and Ronnback 2004) which might reduced shoot density as well as above ground biomass. Mechanical damage may cause fragmentation of habitats that may initiate a large-scale decline (Walker et al. 1986, Short and Wyllie-Echeverria 1996, Burdick and Short 1999). Since seaweed farming has a lot of social economic merit to the communities involved there is a need to have a way to balance between these with the environmental impact on seagrass bed, probably by changing the method of farming like bottom-off plots (tie-tie) and promote the use of floating line plots (Msuya et al. 1996).

The significant higher macrofauna abundance in Jambiani as compared to Chwaka Bay could also be due to the fact that seagrass meadow found at Jambiani (i.e. dominated by $T$. hemprichii) formed a preferred habitat for macrofauna species. The community structure of seagrass meadows, regarding the animals, is not a fixed or constant attribute for any particular seagrass species or combination of species. Meadows with the same composition of seagrass species may 
host a very diverse benthic macrofauna, with very little similarity (Eklöf et al. 2005). The lower abundance of macrofauna in Chwaka Bay could itself have substantial effects at the system level, as benthic macrofauna perform a number of important functions in seagrass beds, such as detritivory and filtration. An example is suspension feeding bivalves which have been shown to benefit from seagrass for shelter, while simultaneously increasing sediment nutrient levels and benefiting seagrasses in a mutualistic relationship (e.g. Peterson and Heck 2001). This implies that the higher abundance of macrofauna encountered in Jambiani could have a positive feed-back effect on the seagrass, further increasing the primary production and higher biomass.

In conclusion, our findings indicate that seagrass and macrofauna diversity in the East Coast of Zanzabar was relatively stable in different seasons. However, it was clearly shown that seaweed farming affects the underlying seagrass beds by decreasing seagrass biomass. The decrease in seagrass biomass has a direct link with the decrease in the number of macrofauna species that depend on them. The seaweed farming involves a lot of human activities such as physical removal of seagrasses for creating space for seaweed farms, back and forth movement of farmers in the seaweed farms and boat anchoring (while harvesting seaweeds) all of which contributed to the loss of diversity and biomass of the seagrass meadows. Mechanical damage worldwide is clearly a factor in seagrass loss, though the overall size of this impact is often considered small. However, more data are required to evaluate the damage that may be caused by seaweed farming on seagrass beds using both methods. With such information sustainable management strategies can be designed.

\section{ACKNOWLEDGEMENTS}

This study was supported by the Marine Science for Management (MASMA) grant, seagrass project. The authors are indebted to the management and staff at the Institute of Marine Sciences, Zanzibar for institutional and logistic support. Mr. Thomas Buluda and Ms. Mariam Hamisi are highly acknowledged for their support during field execution. We are also indebted to the anonymous reviewer for their positive comments and suggestions.

\section{REFERENCES}

Bandeira SO and Gell F 2003 The Seagrasses of Mozambique and Southeastern Africa. In F. Short and E. Green. Seagrass Atlas of the World. World Conservation Monitoring Centre. University of California Press. 105-112 pp.

Bergman KC, Svensson S and Ohman MC 2001 Influence of algal farming on fish assemblages. Marine Poll. Bull. 42: $1379-1389$

Burdick- DM and Short FT 1999 The effects of boat docks on eelgrass beds in coastal waters of Massachusetts. Env. Mgmt. 23: $231-240$

Coen LD, Heck Jr. KL 1991 The interacting effects of siphon nipping and habitat on bivalve (Mercenaria mercenaria (L.)) growth in a subtropical seagrass (Halodule wrightii Aschers.) meadow. J. Exp. Mar. Biol. and Ecol. 145: 1-13.

Coles RG, Lee Long WJ and Squire LC 1985 Seagrass beds and prawn nursery grounds between Cape York and Cairns. Qld. Dept. Primary Indust. Information Series. Q185017.

Creed JC and Amado Filho GM 1999 Disturbance and recovery of the macroflora of a seagrass (Halodule wrightii Ascherson) meadow in the Abrolhos Marine National Park, Brazil: an experimental evaluation of anchor damage. J. Exp. Mar. Biol. Ecol. 235: 285-306

Daby D 2003 Effects of seagrass bed removal for tourism purposes in a Mauritian Bay. Evir. Poll. 125: 313324.

de la Torre Castro M and Rönnbäck P 2004 Links between humans and seagrass - 
example from tropical East Africa. Ocean Coastal Mgnt. 47: 361-387

Den Hartog C 1984 The seagrasses of the World: North Holland Publication Limited. 275 pp.

Duarte CM 2002 The future of seagrass beds. Envir. Cons. 29: $192-206$

Eklöf JS, de la Torre-Castro M, Adelsköld L, Kautsky N and Jiddawi NS 2005 Differences in macromacrofauna and seagrass assemblages in seagrass beds with and without seaweed farms. Est. Coast. Shelf Sci. 63: 385-396

Eklöf JS, de la Torre-Castro M, Nilsson C and Rönnbäck P 2006 How do seaweed farms influence fishery catches in a seagrass-dominated setting in Chwaka Bay, Zanzibar? Aquat. Liv. Res. 19: 137 - 147

Fortes MD 1988 Mangrove and seagrass beds of East Asia: Habitat under stress. Ambio 17: 207 - 213

Green EP and Short FT 2003 World Atlas of Seagrasses. University of Califormia Press, Berkeley, 298 pp.

Hamisi, MI, Lyimo TJ and Muruke MHS 2004 Cyanobacterial occurrence and diversity in seagrass meadows in coastal Tanzania. West. Ind. Ocean J. of Mar. Sci. 3(2): $113-122$.

Holdich DM, Jones JA 1983 Tanaids Keys and notes for the identification of species. In: Kermack, D.M., Barnes, R.S.K. (Eds.),Synopsis of the British Fauna, vol. 27. Cambridge University Press, Cambridge, 98 pp.

Larkum AWD, McComb AJ and Shepherd SA (Eds.) 1989 Biology of the Seagrasses with Special Reference to the Australian Region. Elsevier Science Publishers. Amsterdam 841pp.

Lobban CS and Harrison PJ 1994 Seaweed Ecology and Physiology. New York: Cambridge University Press. 366 pp.

Lugendo BR, Mgaya YD and Semesi AK 1999 The seagrass and associated macroalgae at selected beaches along Dar Es Salaam Coast. In Richmond MD and Francis J (Eds.) Marine Science Development in Tanzania and East
Africa. WIOMSA Book Series 1: 359 373.

Lyimo TJ, Mvungi EF, Lugomela $\mathrm{C}$ and Björk M 2006 Seagrass biomass and productivity in seaweed and non-seaweed farming areas in the East Coast of Zanzibar, Tanzania. West. Ind. Ocean J. Mar. Sci. 5 (2): 141 - 152

Martin ARO and Bandeira SO 2001 Biomass distribution and leaf nutrient concentrations and resorption of Thalassia hemprichii at Inhaca Island, Mozambique. South Afri. J. Bot. 67: $439-442$

Moberg F and Rönnbäck P 2003 Ecosystem services of the tropical seascape: interactions, substitutions and restoration. Ocean Coast. Mgnt. 46: 2746.

Msuya FE 1993 Seaweed farming in Zanzibar: An amazing story. ALCOM News 11: 11-15.

Msuya FE 2006 The Impact of Seaweed Farming on the Social and Economic Structure of Seaweed Farming Communities in Zanzibar, Tanzania. In Critchley AT, Ohno $\mathrm{M}$ and Largo DB (Eds) World Seaweed Resources, Version: 1.0, ISBN: 90-75000-80-4, 27 pp. (www.etiis.org.uk).

Msuya FE, Ngoile MA, Shunula JP 1996 The impact of seaweed farming on the macrophytes of east coast of Unguja Island, Zanzibar, Tanzania. Report submitted to the Canadian International Development Agency (CIDA).

Ochieng C and Erftemeijer P 2003 Seagrasses of Tanzania and Kenya. In: Green, E., Short, F. (Eds.), Seagrass Atlas of the World. World Conservation Monitoring Centre. University of California Press, pp. 93-100.

Oliveira EC, Osterlund K and Mtolera MSP 2005 Marine plants of Tanzania: A field guide to the seaweeds and seagrasses. Botany Department, Stockholm University, Sweden.

Peterson BJ, Heck Jr. KL 2001 Positive interactions between suspension-feeding bivalves and seagrass - a facultative 
mutualism. Mar. Ecol. Prog. Ser. 213, 143-155.

Pettersson-Löfquist P 1995 The development of open water algae farming in Zanzibar; reflections on the socioeconomic impact. Ambio 24: 487 491

Richmond MD (ed) 2002 A Field Guide to the Seashores of Eastern Africa and the Western Indian Ocean Islands. Sida/SAREC-UDSM. $461 \mathrm{pp}$.

Ronnback P, Bryceson I and Kautsky N 2002 Coastal aquaculture development in Eastern Africa and Western Indian Ocean: Prospects and problems for food security and local economies. Ambio 31: $537-542$

Semesi IS 2002 Ecological and socioeconomic impacts of farmed Eucheuma seaweeds in Zanzibar, Tanzania. M.Sc. Thesis Agricultural University of Norway. $77 \mathrm{pp}$

Shechambo, F., Z. Ngazy and F.E. Msuya.
1996. Socio-Economic Impacts of Seaweed Farming in the East Coast of Zanzibar, Tanzania. Report submitted to the Canadian International Development Agency (CIDA), Institute of Marine Sciences, University of Dar es Salaam, Zanzibar, Tanzania, IMS 1997/06. 81p.

Short FT and Coles RG 2001 Global Seagrass Research Methods. Elsevier, Amsterdam 471 pp.

Short FT and Wyllie-Echeverria S 1996 Natural and human-induced disturbances of seagrasses. Env. Cons. 23: 17-27

Wakibia JG 1995 The potential humaninduced impacts on the Kenyan seagrasses. UNESCO Report in Marine Sciences 66: $176-187$

Walker DI, Lukatelich RJ, Bastyan G and McComb AJ 1989 Effects of boat mooring on seagrass beds near Perth, Western Australia. Aq. Bot. 36: 69-77

Zar JH 1996 Biostatistical Analysis (3 ed.). Prentice-Hall. Inc., New York. 